\title{
Targeted ultra-deep sequencing reveals recurrent and mutually exclusive mutations of cancer genes in blastic plasmacytoid dendritic cell neoplasm
}

\author{
Albrecht Stenzinger ${ }^{1, *}$, Volker Endris ${ }^{1, *}$, Nicole Pfarr $^{1}$, Mindaugas Andrulis ${ }^{1}$, Korinna \\ Jöhrens ${ }^{2}$, Frederick Klauschen ${ }^{2}$, Udo Siebolts ${ }^{3}$, Thomas Wolf ${ }^{1}$, Philipp-Sebastian \\ Koch $^{4}$, Miriam Schulz ${ }^{5}$, Wolfgang Hartschuh ${ }^{6}$, Sergij Goerdt ${ }^{4}$, Jochen K. Lennerz ${ }^{7,10}$, \\ Claudia Wickenhauser ${ }^{3}$, Wolfram Klapper ${ }^{8}$, Ioannis Anagnostopoulos ${ }^{2, * *}$ and Wilko \\ Weichert ${ }^{1,9}$,** \\ ${ }^{1}$ Institute of Pathology, University Hospital Heidelberg, Germany \\ 2 Institute of Pathology, Charité University Hospital, Berlin, Germany \\ ${ }^{3}$ Institute of Pathology, University Hospital Halle and Institute of Pathology, University Hospital Leipzig, Germany \\ ${ }^{4}$ Department of Dermatology, Venereology and Allergology, University Medical Center and Medical Faculty Mannheim, \\ University of Heidelberg, Mannheim, Germany \\ ${ }^{5}$ German Red Cross Blood Service and Institute for Transfusion Medicine and Immunohematology, Goethe University Medical \\ School, Frankfurt, Germany \\ ${ }^{6}$ Department of Dermatology, University Hospital Heidelberg, Germany \\ ${ }^{7}$ Institute of Pathology, University of Ulm, Germany \\ 8 Department of Pathology, Hematopathology Section and Lymph Node Registry, Christian-Albrechts-University of Kiel, \\ Germany \\ ${ }^{9}$ National Center for Tumor Diseases, Heidelberg, Germany \\ 10 Present address: Harvard Medical School, Massachusetts General Hospital, Department of Pathology, Boston, MA, USA \\ * These authors contributed equally to this work \\ ** These authors share last authorship \\ Correspondence to: Albrecht Stenzinger, email: albrecht.stenzinger@med.uni-heidelberg.de
}

loannis Anagnostopoulos, email: loannis.Anagnostopoulos@charite.de

Keywords: blastic plasmacytoid dendritic cell neoplasm, BPDCN, recurrent mutations, mutually exclusive mutations, next generation sequencing, ATM, KRAS, NRAS, CDKN2A

Received: May 20, $2014 \quad$ Accepted: July 15, $2014 \quad$ Published: July 16, 2014

This is an open-access article distributed under the terms of the Creative Commons Attribution License, which permits unrestricted use, distribution, and reproduction in any medium, provided the original author and source are credited.

\section{ABSTRACT}

Blastic plasmacytoid dendritic cell neoplasm (BPDCN) is a rare haematopoietic malignancy characterized by dismal prognosis and overall poor therapeutic response. Since the biology of BPDCN is barely understood, our study aims to shed light on the genetic make-up of these highly malignant tumors. Using targeted high-coverage massive parallel sequencing, we investigated 50 common cancer genes in 33 BPDCN samples. We detected point mutations in NRAS (27.3\% of cases), ATM (21.2\%), MET, KRAS, IDH2, KIT (9.1\% each), APC and RB1 (6.1\% each), as well as in VHL, BRAF, MLH1, TP53 and RET ( $3 \%$ each). Moreover, NRAS, KRAS and ATM mutations were found to be mutually exclusive and we observed recurrent mutations in NRAS, IDH2, APC and ATM. CDKN2A deletions were detected in $27.3 \%$ of the cases followed by deletions of RB1 (9.1\%), PTEN and TP53 (3\% each). The mutual exclusive distribution of some mutations may point to different subgroups of BPDCN whose biological significance remains to be explored. 


\section{INTRODUCTION}

Blastic plasmacytoid dendritic cell neoplasm (BPDCN) is an orphan disease with a very aggressive clinical course resulting in median survival times of 12-14 months [1,2]. The male-to-female sex ratio is approximately 2.0-3.5:1 and the mean age at diagnosis is 65-70 years. There is no standardized therapeutic approach [3] and despite initial response to chemotherapy, patients show a very high relapse rate, which points to an overall low efficacy of current therapeutic regimens [4-8].

Initially named blastic NK/T cell lymphoma or agranular CD4+/CD56+ hematodermic neoplasm/tumour $[6,9,10,11]$, BPDCN is -according to the current WHO classification- classified as an acute myeloid leukemiarelated precursor neoplasm [12] that has been shown to derive from precursors of plasmacytoid dendritic cells $[13,14,15,16]$. The genetic basis of this malignancy, however, whose comprehension may yield new and more efficient therapeutic strategies, remains largely enigmatic [17]. As with other rare diseases, the low prevalence of BPDCN and its only quite recent recognition as a distinct tumour entity are major obstacles for comprehensive and systematic clinical and biological research efforts. Consequently, until now only few studies with limited numbers of cases have focused on the genetic foundations of BPDCN, mainly investigating copy number variations of tumor suppressor genes including TP53 and RB1 $[18,19,20,21]$. Two more recent studies [18, 22] also addressed somatic point mutations in the genome of BPDCN. To complement previous efforts and to gain more insight into the genetic basis of BPDCN, we performed targeted ultra-deep semiconductor-based massive parallel sequencing of 50 cancer-related genes [23] in 33 formalinfixed, paraffin embedded primary BPDCN samples and additionally assayed CDKN2A copy numbers.

\section{RESULTS}

Thirty-three cases of BPDCN were analyzed for somatic mutations of 50 common cancer genes by ultradeep targeted semiconductor-based massive parallel sequencing. A detailed overview of detected SNPs including allele frequencies is given in supplementary table 1. Patient demographics are described in table 1. Twenty-seven patients $(81.8 \%$ ) were male and the median age was 72 years. Except for one case with manifestation in the nasopharynx, all biopsy specimens were obtained from cutaneous infiltrates.

Sequence analysis performed with an average read depth of 1.552-fold identified point mutations in 14 genes and deletions in 4 genes. As depicted in figure 1, 4 cases (12.1\%) showed no detectable genetic alteration in the 50 genes investigated. For the other 29 cases (87.8\%), the most frequent non-synonymous point mutations were found in NRAS (9/33 cases; 27.3\%) and ATM (7/33; $21.2 \%)$. Point mutations at lower frequencies were detected in MET, KRAS, IDH2 and KIT (3/33; 9.1\% each), APC and RB1 (2/33; 6.1\% each), and VHL, BRAF, MLH1, TP53 and RET (1/33; 3\% each). Deletions were most prevalent in CDKN2A $(9 / 33 ; 27.3 \%)$ followed by RB1 (3/33; 9.1\%), PTEN and TP53 (1/33; 3\%). For CDKN2A deletions we performed a copy number assay to exemplarily validate our sequencing data by an independent method and corroborated all CDKN2A deletions detected by sequencing analysis. Figure 2 summarizes the frequency of genetic alterations (SNP and CNV combined) per gene.

Mutations in either RAS genes or ATM were present in $57.6 \%$ of cases and in a mutually exclusive distribution (figure 1). Notably, 16 (48.5\%) cases displayed somatic alterations in two or more genes.

Figure 3 depicts the type of point mutation and resulting amino acid substitution for all BPDCN

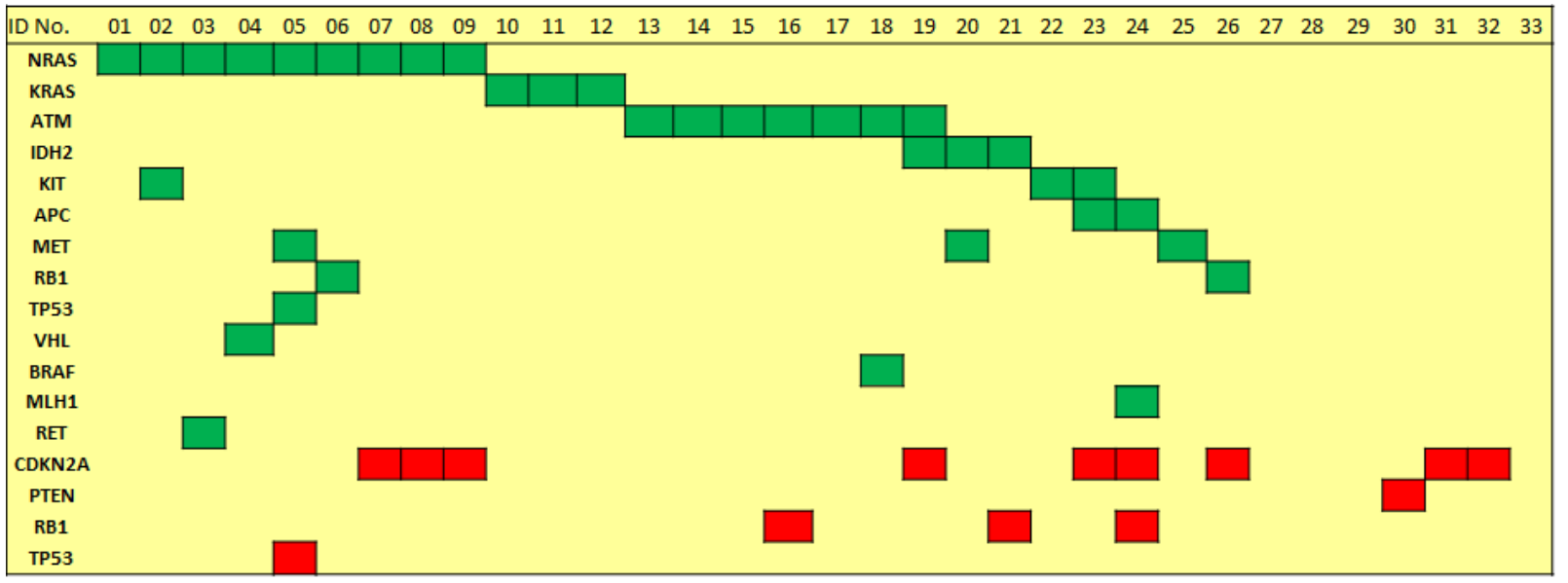

Figure 1: Distribution of recurrent and mutually exclusive point mutations (green color) in known cancer genes as well as of deletions (red color) in CDKN2A, PTEN, TP53 and RB1 across BPDCN cases. 
specimens showing recurrent mutations in NRAS, IDH2, APC and ATM. Except for a nonsense mutation in RB1, mutations in the other genes were of missense type.

Interestingly, as depicted in figures 1 and 3 , one case showed concomitant deletion of one TP53 allele and a double mutation in the remaining TP53 allele and we also found two exceedingly rare mutations in KRAS (p.Gln22Lys and p.Leu23Arg), which have been documented in Cosmic but not reported in the literature yet.

As expected, all mutations in genes coding for the MAPK cascade i.e. KRAS, NRAS genes and BRAF as well as point mutations in the tumor suppressor genes APC, VHL, RB1 and TP53 were classified as deleterious/ damaging by four independent in silico tools (table 2).

Table 1: Basic clinical characteristics of BPDCN cases.

\begin{tabular}{|c|c|c|c|}
\hline ID No. & Age [y] & Sex & Origin of tissue \\
\hline 01 & 77 & $\mathrm{f}$ & skin \\
\hline 02 & 85 & $\mathrm{~m}$ & skin \\
\hline 03 & 81 & $\mathrm{~m}$ & skin \\
\hline 04 & 83 & $\mathrm{~m}$ & skin \\
\hline 05 & 60 & $\mathrm{~m}$ & skin \\
\hline 06 & 69 & $\mathrm{~m}$ & skin \\
\hline 07 & 73 & $\mathrm{~m}$ & skin \\
\hline 08 & 79 & $\mathrm{~m}$ & skin \\
\hline 09 & 67 & $\mathrm{~m}$ & skin \\
\hline 10 & 81 & $\mathrm{~m}$ & skin \\
\hline 11 & 76 & $\mathrm{~m}$ & skin \\
\hline 12 & 69 & $\mathrm{~m}$ & skin \\
\hline 13 & 30 & $\mathrm{~m}$ & skin \\
\hline 14 & 69 & $\mathrm{~m}$ & skin \\
\hline 15 & 83 & $\mathrm{~m}$ & skin \\
\hline 16 & 71 & $f$ & skin \\
\hline 17 & 82 & $\mathrm{~m}$ & skin \\
\hline 18 & 76 & $\mathrm{~m}$ & skin \\
\hline 19 & 54 & $f$ & skin \\
\hline 20 & 64 & $\mathrm{f}$ & skin \\
\hline 21 & 83 & $\mathrm{~m}$ & skin \\
\hline 22 & 89 & $\mathrm{~m}$ & skin \\
\hline 23 & 68 & $\mathrm{f}$ & nasopharynx \\
\hline 24 & 87 & $\mathrm{~m}$ & skin \\
\hline 25 & 60 & $\mathrm{~m}$ & skin \\
\hline 26 & 76 & $\mathrm{~m}$ & skin \\
\hline 27 & 72 & $\mathrm{~m}$ & skin \\
\hline 28 & 65 & $\mathrm{~m}$ & skin \\
\hline 29 & 60 & $\mathrm{~m}$ & skin \\
\hline 30 & 80 & $\mathrm{~m}$ & skin \\
\hline 31 & 52 & $\mathrm{f}$ & skin \\
\hline 32 & 61 & $\mathrm{~m}$ & skin \\
\hline 33 & 72 & $\mathrm{~m}$ & skin \\
\hline
\end{tabular}

f: female, m: male; Age: age at diagnosis, y: years
While mutations in MET and KIT as two potential drug targets were predicted as neutral, we found deleterious missense mutations in ATM and RET, both encoding proteins of the DNA damage response.

\section{DISCUSSION}

Here, we performed targeted high-coverage massive parallel sequencing of 50 common cancer genes in 33 cases of BPDCN. We found recurrent mutations in 4 cancer genes and delineated that NRAS, KRAS and ATM mutations are distributed in a mutually exclusive fashion.

BPDCN is a rare and aggressive hematologic malignancy, whose pathobiology is still largely obscure. Over the last 5 years studies on the genetic foundations

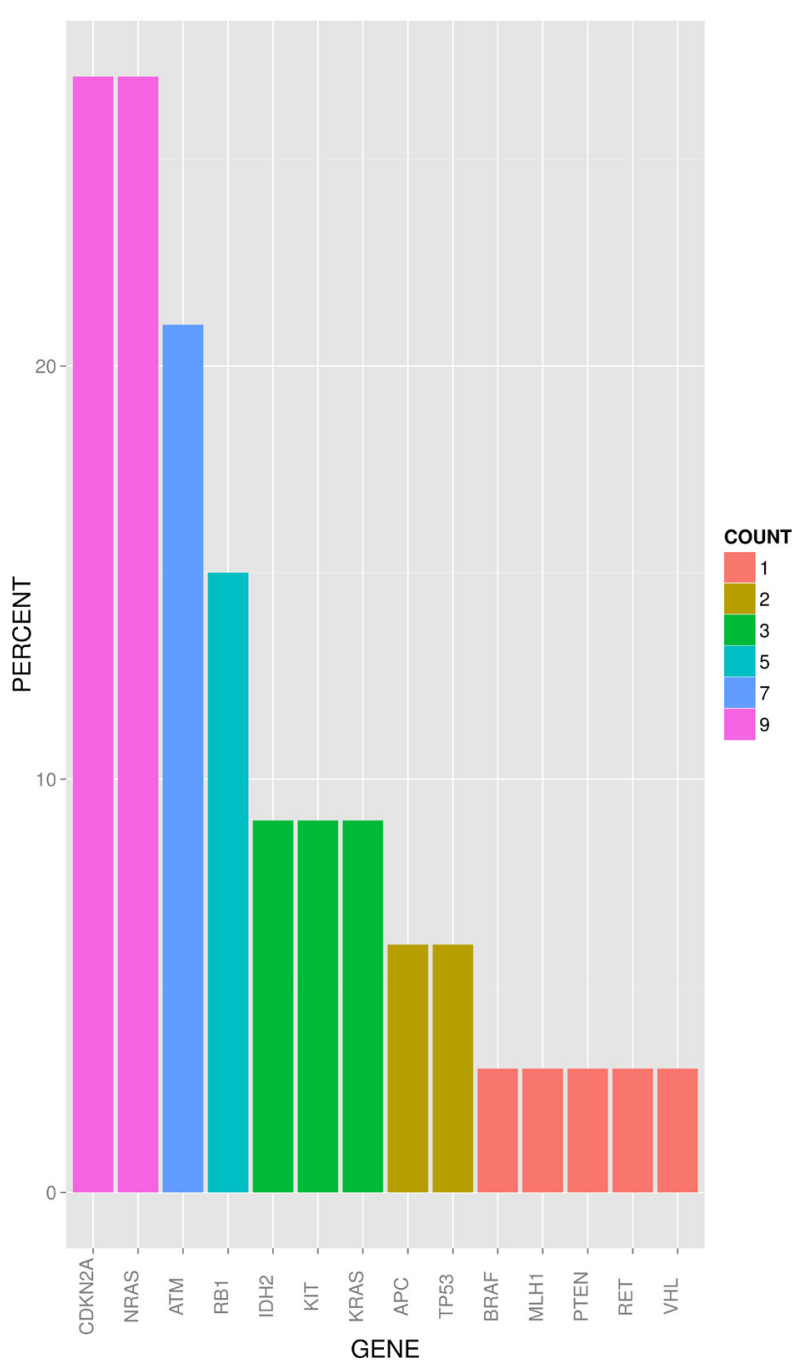

Figure 2: Frequency of genetic alterations (SNP and $\mathrm{CNV}$ ) of known cancer genes in BPDCN (bar plot) in percent (descending order). COUNT indicates absolute numbers of cases. 
Table 2: In silico characterization of gene mutations including COSMIC annotations

\begin{tabular}{|c|c|c|c|c|c|}
\hline Gene/Mutation & $\begin{array}{l}\text { Mutation } \\
\text { Taster }\end{array}$ & PolyPhen & SIFT & PROVEAN & COSMIC \\
\hline NRAS: p.Gly12Asp & $\begin{array}{l}\text { Disease } \\
\text { causing }\end{array}$ & $\begin{array}{l}\text { possibly } \\
\text { damaging }\end{array}$ & Damaging & Deleterious & $\begin{array}{l}\text { COSM564 ( }=450 ; 324 \text { samples in haematopoietic and } \\
\text { lymphoid tissue: i. a. leukemia, myelodysplastic syndrome), } \\
\text { COSM46495 (n=4, leukemia) }\end{array}$ \\
\hline NRAS: p.Gly12Ala & $\begin{array}{l}\text { Disease } \\
\text { causing }\end{array}$ & $\begin{array}{l}\text { possibly } \\
\text { damaging }\end{array}$ & Damaging & Deleterious & $\begin{array}{l}\text { COSM565 ( } \mathrm{n}=52 ; 36 \text { samples in haematopoietic and lymphoid } \\
\text { tissue: i. a. leukemia, BPDCN) }\end{array}$ \\
\hline NRAS: p.Gly12Val & $\begin{array}{l}\text { Disease } \\
\text { causing }\end{array}$ & $\begin{array}{l}\text { possibly } \\
\text { damaging }\end{array}$ & Damaging & Deleterious & $\begin{array}{l}\text { COSM566 ( } \mathrm{n}=72 ; 55 \text { samples in haematopoietic and lymphoid } \\
\text { tissue: i. a. leukemia, myeloproliferative disease) }\end{array}$ \\
\hline NRAS: p.Gly13Val & $\begin{array}{l}\text { Disease } \\
\text { causing }\end{array}$ & $\begin{array}{l}\text { probably } \\
\text { damaging }\end{array}$ & Damaging & Deleterious & $\begin{array}{l}\text { COSM574 ( } \mathrm{n}=61 ; 40 \text { samples in haematopoietic and } \\
\text { lymphoid tissue: i.a. leukemia, myelodysplastic syndromes, } \\
\text { myeloproliferative disease, lymphoma) COSM46502 }(\mathrm{n}=1 \text {, } \\
\text { leukemia) }\end{array}$ \\
\hline NRAS: p.Ala146Val & $\begin{array}{l}\text { Disease } \\
\text { causing }\end{array}$ & $\begin{array}{l}\text { probably } \\
\text { damaging }\end{array}$ & Damaging & Deleterious & No COSMIC entry \\
\hline KRAS: p.Gln22Lys & $\begin{array}{l}\text { Disease } \\
\text { causing }\end{array}$ & $\begin{array}{l}\text { probably } \\
\text { damaging }\end{array}$ & Damaging & Deleterious & $\begin{array}{l}\text { COSM543 ( } \mathrm{n}=9 ; 1 \text { sample in haematopoietic and lymphoid } \\
\text { tissue: leukemia) }\end{array}$ \\
\hline KRAS: p.Leu23Arg & $\begin{array}{l}\text { Disease } \\
\text { causing }\end{array}$ & $\begin{array}{l}\text { probably } \\
\text { damaging }\end{array}$ & Damaging & Deleterious & $\begin{array}{l}\operatorname{COSM} 303853(\mathrm{n}=1 ; 1 \text { sample in haematopoietic and lymphoid } \\
\text { tissue: leukemia) }\end{array}$ \\
\hline KRAS: p.Lys117Asn & $\begin{array}{l}\text { Disease } \\
\text { causing }\end{array}$ & $\begin{array}{l}\text { probably } \\
\text { damaging }\end{array}$ & Damaging & Deleterious & $\begin{array}{l}\text { COSM28519 }(\mathrm{n}=6 ; 2 \text { samples in haematopoietic and lymphoid } \\
\text { tissue: leukemia) }\end{array}$ \\
\hline ATM: p.Phe858Leu & Polymorphism & $\begin{array}{l}\text { possibly } \\
\text { damaging }\end{array}$ & Tolerated & Deleterious & $\begin{array}{l}\text { COSM21826 ( } 3 \text { samples in haematopoietic and lymphoid tissue: } \\
\text { Lymphoma) }\end{array}$ \\
\hline ATM: p.Pro1296Ser & Polymorphism & $\begin{array}{l}\text { probably } \\
\text { damaging }\end{array}$ & Damaging & Deleterious & no COSMIC entry \\
\hline ATM: p.Ile2888Thr & $\begin{array}{l}\text { Disease } \\
\text { causing }\end{array}$ & $\begin{array}{l}\text { probably } \\
\text { damaging }\end{array}$ & Damaging & Deleterious & $\begin{array}{l}\text { COSM21679 ( } 2 \text { samples in haematopoietic and lymphoid tissue: } \\
\text { leukemia, lymphoma) }\end{array}$ \\
\hline IDH2: p.Arg140Gln & $\begin{array}{l}\text { Disease } \\
\text { causing }\end{array}$ & $\begin{array}{l}\text { probably } \\
\text { damaging }\end{array}$ & Damaging & Deleterious & $\begin{array}{l}\text { COSM41590 ( } \mathrm{n}=379 ; 378 \text { samples in haematopoietic and } \\
\text { lymphoid tissue: i. a. BPDCN, myeloproliferative disease, } \\
\text { myelodysplastic syndrome, Leukemia) }\end{array}$ \\
\hline KIT: p.Met541Leu & Polymorphism & benign & Tolerated & Neutral & $\begin{array}{l}\text { COSM28026 ( } \mathrm{n}=31 ; 16 \text { samples in haematopoietic and } \\
\text { lymphoid tissue: pediatric Mastocytosis, myeloid malignancies) }\end{array}$ \\
\hline APC: p.Ala1582Pro & $\begin{array}{l}\text { Disease } \\
\text { causing }\end{array}$ & $\begin{array}{l}\text { probably } \\
\text { damaging }\end{array}$ & Damaging & Deleterious & no COSMIC entry \\
\hline MET: p.Glu168Asp & Polymorphism & $\begin{array}{l}\text { possibly } \\
\text { damaging }\end{array}$ & Tolerated & Neutral & $\begin{array}{l}\text { COSM706 }(n=2), \text { COSM29811 }(n=4 ; 1 \text { sample in } \\
\text { haematopoietic and lymphoid tissue: Langerhans cell } \\
\text { histiocytosis })\end{array}$ \\
\hline MET: p.Asn375Ser & $\begin{array}{l}\text { Disease } \\
\text { causing }\end{array}$ & benign & Tolerated & Neutral & COSM710 $(n=3), \operatorname{COSM} 28925(n=18)$ \\
\hline RB1: p.Asp332Gly & $\begin{array}{l}\text { Disease } \\
\text { causing }\end{array}$ & $\begin{array}{l}\text { probably } \\
\text { damaging }\end{array}$ & Damaging & Deleterious & no COSMIC entry \\
\hline RB1: p.Arg358* & $\begin{array}{l}\text { Disease } \\
\text { causing }\end{array}$ & Nonsense & Nonsense & Nonsense & $\operatorname{CosM} 879(n=6)$ \\
\hline TP53: p.His179Arg & $\begin{array}{l}\text { Disease } \\
\text { causing }\end{array}$ & $\begin{array}{l}\text { probably } \\
\text { damaging }\end{array}$ & Damaging & Deleterious & $\operatorname{COSM} 10889(\mathrm{n}=114), \operatorname{COSM} 87198(\mathrm{n}=5)$ \\
\hline TP53: p.Asp281Tyr & $\begin{array}{l}\text { Disease } \\
\text { causing }\end{array}$ & $\begin{array}{l}\text { probably } \\
\text { damaging }\end{array}$ & Damaging & Deleterious & $\begin{array}{l}\text { COSM11516 }(\mathrm{n}=10 ; 1 \text { sample in haematopoietic and lymphoid } \\
\text { tissue: lymphoma) }\end{array}$ \\
\hline VHL: p.Pro81Ser & $\begin{array}{l}\text { Disease } \\
\text { causing }\end{array}$ & $\begin{array}{l}\text { possibly } \\
\text { damaging }\end{array}$ & Damaging & Deleterious & COSM17721 $(n=16) \operatorname{COSM} 144163(n=1)$ \\
\hline BRAF: p.Gly469Ala & $\begin{array}{l}\text { Disease } \\
\text { causing }\end{array}$ & $\begin{array}{l}\text { probably } \\
\text { damaging }\end{array}$ & Damaging & Deleterious & $\begin{array}{l}\text { COSM460 ( }=31 ; 6 \text { samples in haematopoietic and lymphoid } \\
\text { tissue: leukemia, lymphoma), COSM29608 }(n=21)\end{array}$ \\
\hline MLH1:p.Arg385Cys & $\begin{array}{l}\text { Disease } \\
\text { causing }\end{array}$ & $\begin{array}{l}\text { probably } \\
\text { damaging }\end{array}$ & Damaging & Deleterious & $\operatorname{COSM} 1422593(n=1)$ \\
\hline RET:p.Ser649Leu & $\begin{array}{l}\text { Disease } \\
\text { causing }\end{array}$ & $\begin{array}{l}\text { probably } \\
\text { damaging }\end{array}$ & Damaging & Neutral & no COSMIC entry \\
\hline
\end{tabular}


of BPDCN revealed a peculiar genotype with a complex karyotype and recurrent deletions in several tumor suppressor genes, such as RB1, TP53, CDKN2A and CDKN2B $[19,20,21,28]$. While the data on copy number variations seem to be rather specific for BPDCN among hematologic neoplasms, recent work [18, 29] demonstrated point mutations in TET2 und TP53 in the genome of BPDCN thereby genetically relating BPDCN to a broad range of myeloid malignancies, where recurrent mutations particularly in the tumour suppressor TET2 but also in TP53 are highly prevalent $[30,31]$. In accord with these reports, we detected deletions, which were most prevalent for CDKN2A and less frequent for RB1, TP53 and PTEN. Moreover we found point mutations in TP53, IDH2, KRAS and NRAS further underpinning a genetic relation between BPDCN and myeloid malignancies, including acute myeloid leukemia and myelodysplastic syndrome. Thereby, our findings extend the observations of prior studies and support the genetic rationale for the current WHO classification of BPDCN as a distinct precursor neoplasm that relates to acute myeloid leukemia. In this context it is notable that we did not find mutations in other genes that have been described in myeloid malignancies, such as FLT3, NPM1, IDH1, JAK2, and EZH2. A very recent study by Menezes et al [22], who used a combined approach of whole exome sequencing-based identification of major genetic aberrations and targeted resequencing of 25 BPDCN, found similar frequencies of mutations in NRAS and corroborated TET2 mutations albeit at a lower frequency as reported previously [18, 29]. Additionally, they identified mutations in genes not included in our gene panel, namely in ASXL1 and in the transcription factors IKZF1-3 and ZEB2. Taken together, these findings strongly support the view that BPDCN is a distinct entity within the spectrum of myeloid malignancies.

Interestingly, we discovered missense mutations in DNA damage response genes, i.e. MLH1 and ATM in a substantial number of cases. Of three ATM variants, we have detected in our cohort, two are already reported in the Cosmic database and all three are classified as damaging by the majority of the in silico prediction models used herein. ATM aberrations have been mainly implicated

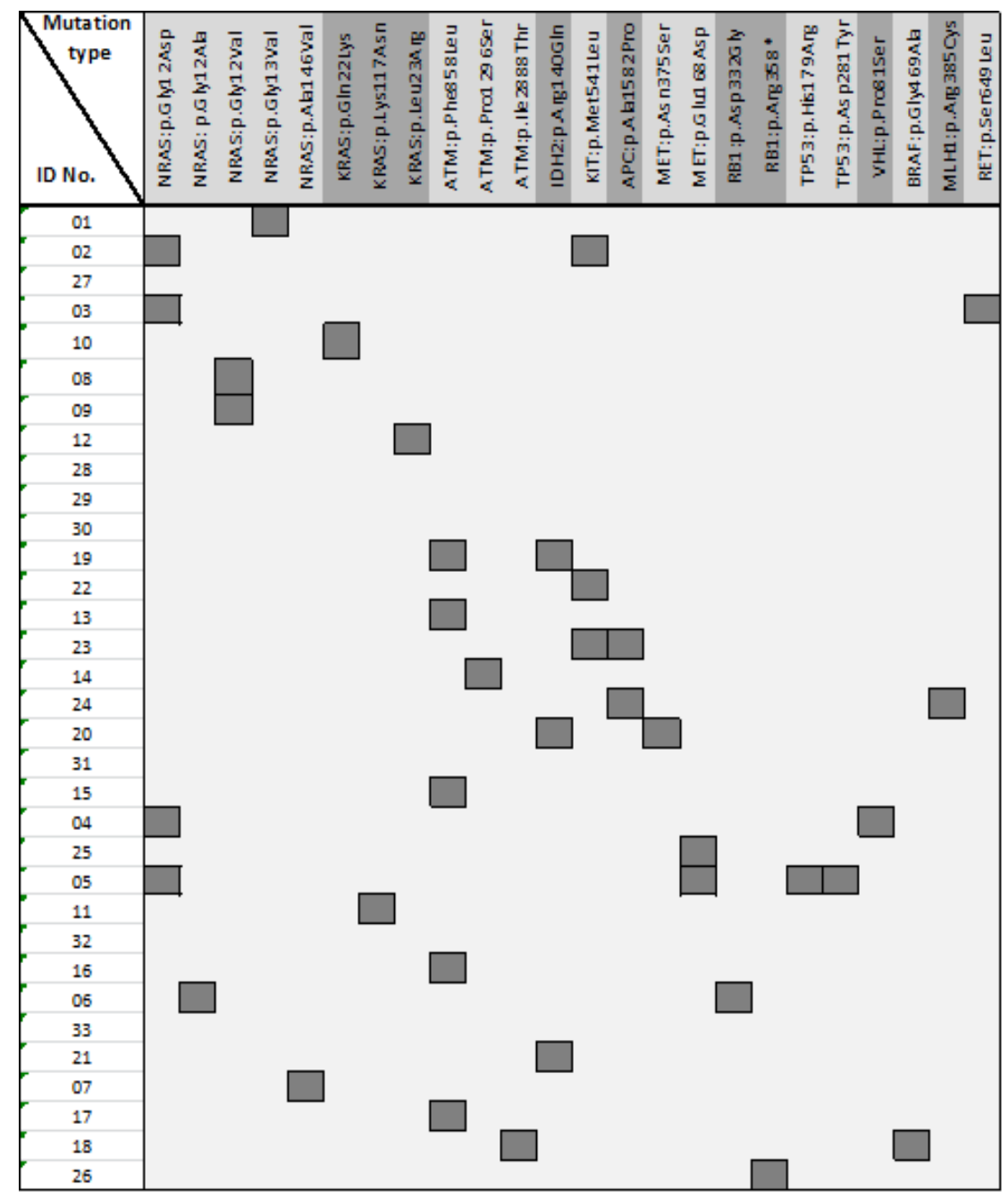

Figure 3: Distribution of non-synonymous somatic mutation types in known cancer genes across BPDCN samples. Amino acid substitutions as indicated. 
in the development of lymphomas, including T-cell prolymphocytic leukemia [32], mantle cell lymphoma [33], diffuse large B-cell lymphoma [34] and B-cell chronic lymphocytic leukemia [35]. Although we do not know yet what these ATM mutations actually mean for BPDCN biology, In the light of the above mentioned studies, our genetic data may point to a shared trait with lymphoid malignancies. In line with these findings, BPDCN express also molecules that can be found in malignant lymphomas, such as CD4 and CD123 and it has been demonstrated in mice that normal plasmacytoid dendritic cells retain remarkable differentiation plasticity and can derive from both myeloid and lymphoid progenitors [36]. Also, a recent study conducted by Sapienza et al [37] found BPDCN to display an ambiguous expression profile that indeed related to both acute lymphoid and acute myeloid leukemia. Moreover, although these data do not stem from randomized clinical trials and therefore have to be interpreted carefully, several clinical reports have demonstrated a considerable efficacy of acute lymphoid leukemia-like protocols in BPDCN treatment $[38,39]$.

While it is well known that RAS signaling plays a role in other hematologic malignancies, our study shows for the first time that BPDCN specimens have mutually exclusive mutations in NRAS and KRAS and recurrent mutations in NRAS. Our study suggests that the prevalence of RAS mutations in approximately $35 \%$ of BPDCN even exceeds the ones reported for other hematological neoplasms known to harbor RASmutations, namely juvenile myelomonocytic leukemia (JMML), chronic myelomonocytic leukemia (CMML), acute myeloid leukemia (AML), myelodysplastic syndrome (MDS), acute lymphoblastic leukemia (ALL) and multiple myeloma (MM) [40]. As already reported for these neoplasms, BPDCN also shows a clear predominance of NRAS mutations over KRAS mutations. Although tremendous research efforts are being made, powerful and clinically effective inhibition of mutated RAS is still at a distant prospect. However, given the high prevalence of mutated RAS genes, targeting Ras or downstream effectors of the MAPK-pathway such as MEK and ERK $[41,42]$ would be a valuable treatment option for BPDCN.

Since mutations in NRAS and KRAS as well as in ATM were found to be recurrent and mutually exclusive, it is tempting to speculate whether these data point to genetically distinct subgroups within the BPDCN phenotype.

At this point the lack of reliable BPDCN models precludes functional analysis or the study of biological implications of our genetic data. Furthermore, the overall rarity of BPDCN precludes analysis of clinical course or outcome data. Nonetheless, our sample size of 33 primary tumour samples at least equals or exceeds the number of specimens in prior studies $[18,22]$. In conjunction with these studies, here, we extend the genetic framework of BPDCN, which is an important step in understanding the pathobiology of BPDCN and may also aid in finding novel therapeutic options for this orphan disease.

\section{MATERIAL AND METHODS}

\section{Ethics statement}

This study was conducted as an anonymized caseand specimen review via the tissue bank of the National Center for Tumor Diseases (NCT, Heidelberg, Germany). All experiments were performed in accordance with the Declaration of Helsinki.

\section{Samples}

Formalin-fixed, paraffin embedded tissue from 33 cases of BPDCN were obtained from the Institute of Pathology and Department of Dermatology, University Hospital Heidelberg, the Institute of Pathology, Charité University Hospital, Berlin, the Institute of Pathology at the University of Leipzig, the Department of Pathology, Christian-Albrechts-University of Kiel, and the Department of Dermatology, Venereology and Allergology, University Medical Center and Medical Faculty Mannheim, University of Heidelberg. All cases were diagnosed by experienced haematopathologists (AM, IA, KJ, WK, CW) according to the criteria of the World Health Organization classification of heamatopoietic and lymphoid tissue [12]. Patient data were anonymized. Due to the fact that the majority of cases had been sent for consultation no follow-up data were available.

\section{DNA extraction}

Extraction of genomic DNA was performed by proteinase $\mathrm{K}$ digestion and fully automated purification using the QIASymphonySP (Qiagen, Hilden, Germany). The total DNA content was measured using the QuBit HS DNA Assay (Life Technologies, Darmstadt, Germany), followed by measuring the amount of amplifiable DNA using quantitative PCR [23].

\section{Library preparation and semiconductor sequencing}

For this study the multiplex PCR based Ion Torrent AmpliSeq cancer Hotspot panel version 2 (Life Technologies, Darmstadt, Germany) was used, covering approx. 2,800 COSMIC annotated mutations in the following 50 key cancer genes: ABL1, AKT1, 
ALK, APC, ATM, BRAF, CDH1, CDKN2A, CSF1R, CTNNB1, EGFR, ERBB2, ERBB4, EZH2, FBXW7, FGFR1, FGFR2, FGFR3, FLT3, GNA11, GNAS, GNAQ, HNF1A, HRAS, IDH1, IDH2, JAK2, JAK3, KDR, KIT, KRAS, MET, MLH1, MPL, NOTCH1, NPM1, NRAS, PDGFRA, PIK3CA, PTEN, PTPN11, RB1, RET, SMAD4, SMARCB1, SMO, SRC, STK11, TP53, and VHL. Amplicon library preparation was performed using approximately $10 \mathrm{ng}$ of DNA as advised by the manufacturer. Briefly, the DNA was mixed with the primer pool, containing all primers for generating the 207 amplicons, and the AmpliSeq HiFi Master Mix and transferred to a PCR cycler (Biometra, Göttingen,Germany). PCR cycling conditions were as follows: Initial denaturation: $99^{\circ} \mathrm{C}$ for $2 \mathrm{~min}$, cycling: 21 cycles of $99^{\circ} \mathrm{C}, 15 \mathrm{sec}$ and $60^{\circ} \mathrm{C}, 4 \mathrm{~min}$. After the end of the PCR reaction, primer end sequences were partially digested using FuPa reagent as instructed, followed by the ligation of barcoded sequencing adapters (Ion Xpress Barcode Adapters, Life Technologies, Darmstadt, Germany). The final library was purified using AMPure XP magnetic beads (Beckman Coulter, Krefeld, Germany) and quantified using qPCR (Ion Library Quantitation Kit, Life Technologies, Darmstadt, Germany) on a StepOne Plus Instrument (Life Technologies, Darmstadt, Germany). The individual libraries were diluted to a final concentration of $100 \mathrm{pM}$ and eight to ten libraries were pooled and processed to library amplification on Ion Spheres using the Ion OneTouch 2 instrumentation with the 200 bp chemistry. Unenriched libraries were qualitycontrolled using Ion Sphere quality control measurement on a QuBit instrument. After library enrichment (Ion OneTouch ES), the library was processed for sequencing using the Ion Torrent 200 bp sequencing chemistry and the barcoded eight to ten libraries were loaded onto a single 318 chip.

\section{Data analysis}

Raw data analysis was performed using Ion Torrent Software Suite (Version 3.6 and 4.0, respectively). The reads were aligned to the human reference sequence build 38 (hg19) using the TMAP aligner implemented in the Torrent Suite software. Detection of single base pair variants and insertion-deletion polymorphisms (InDels) compared to the human reference sequence was performed using either Ion Torrent Variant Caller (3.6 and 4.0). Detection thresholds for SNPs and InDels were set at an allele frequency of 5\%. Variants were annotated and filtered against the dbSNP and COSMIC databases and screened for possible splice site effect using the CLC genomics Suite 6 (CLCbio, Aarhus, Denmark). Copy number variation was determined using the coverage analysis plug-in of the Torrent Suite software.

\section{Copy number alterations}

All tissue samples were analyzed for CDKN2A copy number using a Taqman ${ }^{\circledR}$ copy number assay (Life Technologies, Carlsbad, CA) to measure copy number variation at the CDKN2A locus. The assay is a duplex polymerase chain reaction (PCR) for the CDKN2A gene and the reference gene, RNaseP (normalizer), using $10 \mathrm{ng}$ DNA in quadruplicate PCR according to the manufacturer's protocol and run on the StepOnePlus real time PCR instrument (Life Technologies). The results were calculated as a ratio relative to a 2-copy control using the Copy Caller software (Life Technologies). Loss of CDKN2A was defined as $\leq 1.5$ copies, no loss was $>1.5$ copies.

\section{In silico analysis of mutations}

The biological impact of the mutations on the structure and function of the respective protein product was predicted in silico by the use of four different software tools: Provean (http://provean.jcvi.org/index.php) [24], Sift (http://sift.jcvi.org/) [25], MutationTaster (http:// www.mutationtaster.org/) [26] and PolyPhen (http:// genetics.bwh.harvard.edu/pph/data/) [27]. Additionally we used the COSMIC (catalogue of somatic mutations in cancer) database to check our sequencing data for somatic mutations that have already been reported elsewhere.

\section{Author contributions}

V.E., N.P. and A.S. performed analysis of the sequence data. T.W., J.K.L. and M.S. contributed to data analysis. A.S. and W.W. coordinated sample acquisition and processing. P.K., M.A., K.J., U.S., W.H., S.G., C.W. and W.K. provided samples and clinical data. A.S., V.E., I.A. and W.W. wrote the manuscript, with contributions from M.A., F. K. and J.K.L.. A.S., V.E., W.W. and I.A. directed the research.

\section{ACKNOWLEDGEMENTS}

The excellent technical assistance of Kathrin Steinhauser und Kathrin Lorenz is gratefully acknowledged.

\section{Conflict of interest disclosure}

The authors declare no competing financial interests.

\section{REFERENCES}

1. Julia F, Petrella T, Beylot-Barry M, Bagot M, Lipsker 
D, Machet L, Joly P, Dereure O, Wetterwald M, d'Incan M, Grange F, Cornillon J, Tertian G, Maubec E, Saiag P, Barete S, Templier I, Aubin F, Dalle S. Blastic plasmacytoid dendritic cell neoplasm: clinical features in 90 patients. Br J Dermatol. 2013; 169, 579-86

2. Lee JK, Schiller G. Blastic plasmacytoid dendritic cell neoplasm. Clin Adv Hematol Oncol. 2012; 10: 60-2.

3. Kharfan-Dabaja MA, Lazarus HM, Nishihori T, Mahfouz RA, Hamadani M. Diagnostic and therapeutic advances in blastic plasmacytoid dendritic cell neoplasm: a focus on hematopoietic cell transplantation. Biol Blood Marrow Transplant. 2013; 19: 1006-12.

4. Dalle S, Beylot-Barry M, Bagot M, Lipsker D, Machet L, Joly P, Dompmartin A, d'Incan M, Maubec E, Grange F, Dereure O, Prey S, Barete S, Wetterwald M, Fraitag S, Petrella T. Blastic plasmacytoid dendritic cell neoplasm: is transplantation the treatment of choice? Br J Dermatol, 2010. 162, 74-9.

5. Dietrich S, Andrulis M, Hegenbart U, Schmitt T, Bellos F, Martens UM, Meissner J, Krämer A, Ho AD, Dreger P. Blastic plasmacytoid dendritic cell neoplasia (BPDC) in elderly patients: results of a treatment algorithm employing allogeneic stem cell transplantation with moderately reduced conditioning intensity. Biol Blood Marrow Transplant. 2011; A17:1250-4

6. Feuillard J, Jacob MC, Valensi F, Maynadié M, Gressin R, Chaperot L, Arnoulet C, Brignole-Baudouin F, Drénou B, Duchayne E, Falkenrodt A, Garand R, Homolle E, Husson B, Kuhlein E, Le Calvez G, Sainty D, Sotto MF, Trimoreau F, Béné MC. Clinical and biologic features of CD4(+) CD56(+) malignancies. Blood. 2002; 99: 1556-63.

7. Reimer P, Rüdiger T, Kraemer D, Kunzmann V, Weissinger F, Zettl A, Müller-Hermelink K, Wilhelm M. What is CD4+CD56+ malignancy and how should it be treated? Bone Marrow Transplant. 2003; 32: 637-46.

8. Roos-Weil D, Dietrich S, Boumendil A, Polge E, Bron D, Carreras E, Iriondo Atienza A, Arcese W, Beelen DW, Cornelissen JJ, Kröger N, Milone G, Rossi G, Jardin F, Peters C, Rocha V, Sureda A, Mohty M, Dreger P; European Group for Blood and Marrow Transplantation Lymphoma, Pediatric Diseases, and Acute Leukemia Working Parties. Stem cell transplantation can provide durable disease control in blastic plasmacytoid dendritic cell neoplasm: a retrospective study from the European Group for Blood and Marrow Transplantation. Blood. 2013; 17;121: 440-6.

9. Garnache-Ottou F, Feuillard J, Saas P. Plasmacytoid dendritic cell leukaemia/lymphoma: towards a well defined entity? Br J Haematol. 2007; 136: 539-548.

10. Herling M, Jones D. (2007) CD4+/CD56+ hematodermic tumor: the features of an evolving entity and its relationship to dendritic cells. Am J Clin Pathol. 2007; 127: 687-700.

11. Jacob MC, Chaperot L, Mossuz P, Feuillard J, Valensi F, Leroux D, Béné MC, Bensa JC, Brière F, Plumas J. CD4+ CD56+ lineage negative malignancies: a new entity developed from malignant early plasmacytoid dendritic cells. Haematologica, 2003; 88: 941-55.

12. Facchetti F JD, Petrella T. (2008) Blastic plasmacytoid dendritic cell neoplasms. In: WHO Classification of Tumors of Haematopoietic and Lymphoid Tissues. WHO Classification of Tumors of Haematopoietic and Lymphoid Tissues (Swerdlow SH, Campo E, Harris NL, et al eds) Lyon: IARC; 145-147.

13. Chaperot L, Bendriss N, Manches O, Gressin R, Maynadie M, Trimoreau F, Orfeuvre H, Corront B, Feuillard J, Sotto JJ, Bensa JC, Brière F, Plumas J, Jacob MC. Identification of a leukemic counterpart of the plasmacytoid dendritic cells. Blood. 2001; 97, 3210-7.

14. Jegalian AG, Facchetti F, Jaffe ES. Plasmacytoid dendritic cells: physiologic roles and pathologic states. Adv Anat Pathol. 2009; 16: 392-404.

15. Petrella T, Comeau MR, Maynadié M, Couillault G, De Muret A, Maliszewski CR, Dalac S, Durlach A, Galibert L. (2002) 'Agranular CD4+ CD56+ hematodermic neoplasm' (blastic NK-cell lymphoma) originates from a population of CD56+ precursor cells related to plasmacytoid monocytes. Am J Surg Pathol. 2002; 26: 852-62.

16. Yang GX, Lian ZX, Kikuchi K, Moritoki Y, Ansari AA, Liu YJ, Ikehara S, Gershwin ME. Plasmacytoid dendritic cells of different origins have distinct characteristics and function: studies of lymphoid progenitors versus myeloid progenitors. J Immunol. 2005; 175: 7281-7.

17. Petrella T, Bagot M, Willemze R, Beylot-Barry M, Vergier B, Delaunay M, Meijer CJ, Courville P, Joly P, Grange F, De Muret A, Machet L, Dompmartin A, Bosq J, Durlach A, Bernard P, Dalac S, Dechelotte P, D'Incan M, Wechsler J, Teitell MA. Blastic NK-cell lymphomas (agranular CD4+CD56+ hematodermic neoplasms): a review. Am J Clin Pathol. 2005; 123: 662-75.

18. Jardin F, Ruminy P, Parmentier F, Troussard X, Vaida I, Stamatoullas A, Leprêtre S, Penther D, Duval AB, Picquenot JM, Courville P, Capiod JC, Tilly H, Bastard C, Marolleau JP. TET2 and TP53 mutations are frequently observed in blastic plasmacytoid dendritic cell neoplasm. Br J Haematol. 2011; 153: 413-6.

19. Lucioni M, Novara F, Fiandrino G, Riboni R, Fanoni D, Arra M, Venegoni L, Nicola M, Dallera E, Arcaini L, Onida F, Vezzoli P, Travaglino E, Boveri E, Zuffardi O, Paulli M, Berti E. Twenty-one cases of blastic plasmacytoid dendritic cell neoplasm: focus on biallelic locus 9p21.3 deletion. Blood. 2011; 118: 4591-4.

20. Oiso N, Tatsumi Y, Arao T, Rai S, Kimura M, Nakamura $\mathrm{S}$, Itoh T, Nishio K, Matsumura I, Kawada A. Loss of genomic DNA copy numbers in the p18, p16, p27 and RB loci in blastic plasmacytoid dendritic cell neoplasm. Eur J Dermatol. 2012; 22, 393-4.

21. Wiesner T, Obenauf AC, Cota C, Fried I, Speicher MR, Cerroni L. Alterations of the cell cycle inhibitors p27(KIP1) and $\mathrm{p} 16(\mathrm{INK} 4 \mathrm{a})$ are frequent in blastic plasmacytoid dendritic cell neoplasms. J Invest Dermatol. 2009; 130: 
1152-1157.

22. Menezes J, Acquadro F, Wiseman M, Gómez-López G, Salgado RN, Talavera-Casañas JG, Buño I, Cervera JV, Montes-Moreno S, Hernández-Rivas JM, Ayala R, Calasanz MJ, Larrayoz MJ, Brichs LF, Gonzalez-Vicent M, Pisano DG, Piris MA, Alvarez S, Cigudosa JC. Exome sequencing reveals novel and recurrent mutations with clinical impact in blastic plasmacytoid dendritic cell neoplasm. Leukemia. 2013 Sep 27. doi: 10.1038/leu.2013.283. [Epub ahead of print]

23. Endris V, Penzel R, Warth A, Muckenhuber A, Schirmacher $\mathrm{P}$, Stenzinger A, Weichert W. Molecular diagnostic profiling of lung cancer specimens with a semiconductorbased massive parallel sequencing approach: feasibility, costs, and performance compared with conventional sequencing. J Mol Diagn. 2013; 15, 765-75.

24. Choi Y, Sims GE, Murphy S, Miller JR, Chan AP. Predicting the Functional Effect of Amino Acid Substitutions and Indels. PLoS ONE. 2012; 7: e46688.

25. Kumar P, Henikoff S, Ng PC. Predicting the effects of coding non-synonymous variants on protein function using the SIFT algorithm. Nat Protoc, 2009; 4: 1073-81.

26. Schwarz JM, Rödelsperger C, Schuelke M, Seelow D. MutationTaster evaluates disease-causing potential of sequence alterations. Nat Methods. 2012; 7:575-6.

27. Ramensky V, Bork P, Sunyaev S. Human non-synonymous SNPs: server and survey. Nucleic Acids Res, 2002; 30: 3894-900.

28. Jardin F, Callanan M, Penther D, Ruminy P, Troussard X, Kerckaert JP, Figeac M, Parmentier F, Rainville V, Vaida I, Bertrand P, Duval AB, Picquenot JM, Chaperot L, Marolleau JP, Plumas J, Tilly H, Bastard C. Recurrent genomic aberrations combined with deletions of various tumour suppressor genes may deregulate the G1/S transition in CD4+CD56+ haematodermic neoplasms and contribute to the aggressiveness of the disease. Leukemia. 2009; 23: 698-707.

29. Alayed K, Patel KP, Konoplev S, Singh RR, Routbort MJ, Reddy N, Pemmaraju N, Zhang L, Shaikh AA, Aladily TN, Jain N, Luthra R, Jeffrey Medeiros L, Khoury JD. TET2 mutations, myelodysplastic features, and a distinct immunoprofile characterize blastic plasmacytoid dendritic cell neoplasm in the bone marrow. Am J Hematol. 2013 in press. doi: 10.1002/ajh.23567

30. Lindsley RC, Ebert BL. The biology and clinical impact of genetic lesions in myeloid malignancies. Blood. 2013; 122: 3741-8.

31. Rampal R, Levine RL. Leveraging cancer genome information in hematologic malignancies. J Clin Oncol. 2013; 31: 1885-92.

32. Yuille MA, Coignet LJ, Abraham SM, Yaqub F, Luo L, Matutes E, Brito-Babapulle V, Vorechovský I, Dyer MJ, Catovsky D. ATM is usually rearranged in T-cellprolymphocytic leukaemia. Oncogene. 1998; 16: 789-
96.

33. Schaffner C, Idler I, Stilgenbauer S, Dohner H, Lichter P. Mantle cell lymphoma is characterized by inactivation of the ATM gene. Proc Natl Acad Sci U S A. 2007; 97, 2773 2778 .

34. Grønbaek K, Worm J, Ralfkiaer E, Ahrenkiel V, Hokland P, Guldberg P. ATM mutations are associated with inactivation of the ARF-TP53 tumor suppressor pathway in diffuse large B-cell lymphoma. Blood. 2002; 100: 1430-7

35. Stankovic T, Weber P, Stewart G, Bedenham T, Murray J, Byrd PJ, Moss PA, Taylor AM. (1999) Inactivation of ataxia telangiectasia mutated gene in B-cell chronic lymphocytic leukaemia. Lancet. 1999; 353, $26-9$.

36. Zuniga EI, McGavern DB, Pruneda-Paz JL, Teng C, Oldstone MB. Bone marrow plasmacytoid dendritic cells can differentiate into myeloid dendritic cells upon virus infection. Nat Immunol. 2004; 5: 1227-1234

37. Sapienza MR, Fuligni F, Agostinelli C, Tripodo C, Righi S, Laginestra MA, Pileri A, Mancini M, Rossi M, Ricci F, Gazzola A, Melle F, Mannu C, Ulbar F, Arpinati M, Paulli M, Maeda T, Gibellini D, Pagano L, Pimpinelli N, Santucci M, Cerroni L, Croce CM, Facchetti F, Piccaluga PP, Pileri SA. (2014) Molecular profiling of blastic plasmacytoid dendritic cell neoplasm reveals a unique pattern and suggests selective sensitivity to NF-KB pathway inhibition. Leukemia. 2014 Feb 7. doi: 10.1038/leu.2014.64. [Epub ahead of print]

38. Tsagarakis NJ, Kentrou NA, Papadimitriou KA, Pagoni M, Kokkini G, Papadaki H, Pappa V, Marinakis T, Anagnostopoulos NI, Vadikolia C, Anagnostopoulos A, Angelopoulou MK, Terpos E, Poziopoulos C, Anargyrou K, Rontogianni D, Papadaki T, Psarra A, Kontopidou FN, Skoumi D, Papadhimitriou SI, Paterakis G; Hellenic Dendritic Cell Leukemia Study Group. Acute lymphoplasmacytoid dendritic cell (DC2) leukemia: results from the Hellenic Dendritic Cell Leukemia Study Group. Leuk Res. 2010; 34:438-46.

39. Jegalian AG, Buxbaum NP, Facchetti F, Raffeld M, Pittaluga S, Wayne AS, Jaffe ES. Blastic plasmacytoid dendritic cell neoplasm in children: diagnostic features and clinical implications. Haematologica. 2010; 95: 1873-9.

40. Ward AF, Braun BS, Shannon KM. Targeting oncogenic Ras signaling in hematologic malignancies. Blood. 2012; 120: 3397-406.

41. Hatzivassiliou G, Liu B, O’Brien C, Spoerke JM, Hoeflich KP, Haverty PM, Soriano R, Forrest WF, Heldens S, Chen H, Toy K, Ha C, Zhou W, Song K, Friedman LS, Amler LC, Hampton GM, Moffat J, Belvin M, Lackner MR. ERK inhibition overcomes acquired resistance to MEK inhibitors. Mol Cancer Ther. 2012; 11:1143-54.

42. Roberts PJ, Der CJ. Targeting the Raf-MEK-ERK mitogenactivated protein kinase cascade for the treatment of cance. Oncogene. 2007; 26:3291-310. 
